\title{
Uji efek antibakteri tinta cumi-cumi (Loligo sp.) terhadap bakteri saluran akar gigi
}

\author{
${ }^{1}$ Jimmy Posangi, ${ }^{2}$ Juliatri, ${ }^{3}$ Robert Bara, ${ }^{4}$ Jean Tairas, Jane Wuisan \\ ${ }^{1}$ Fakultas Kedokteran \\ ${ }^{2}$ Program Studi Kedokteran Gigi Fakultas Kedokteran \\ ${ }^{3}$ Fakultas Perikanan dan Ilmu Kelautan \\ ${ }^{4}$ Mahasiswa Program Studi Kedokteran Gigi Fakultas Kedokteran \\ Universitas Sam Ratulangi Manado
}

\begin{abstract}
ABSTRAK
Nekrosis pulpa merupakan kematian pulpa, dapat sebagian atau seluruhnya, yang disebabkan oleh proses lanjutan dari radang pulpa ataupun akibat trauma. Salah satu penanganan nekrosis pulpa yakni perawatan endodontik. Mikroorganisme yang tersisa setelah preparasi maupun setelah pengisian saluran akar merupakan penyebab utama kegagalan perawatan endodontik. Tinta cumi-cumi (Loligo sp.) berkhasiat sebagai antibakteri. Tujuan penelitian ini untuk mengetahui adanya efek antibakteri tinta cumicumi terhadap bakteri saluran akar gigi.

Penelitian ini ialah penelitian eksperimental laboratoris yang menggunakan modifikasi metode Kirby-Bauer, difusi sumur. Isolat bakteri diisolasi dari spesimen saluran akar gigi nekrosis pulpa, ditanam dalam BHA untuk mendapatkan koloni. Tiga koloni yang ditemukan diuji dengan tinta cumi-cumi fraksi etil asetat dan fraksi larut air.

Hasil penelitian menunjukkan adanya daerah hambat bakteri uji pada fraksi etil asetat tinta cumi-cumi. Di lain pihak, tidak adanya daerah hambat bakteri pada fraksi larut air, menginformasikan keberadaan senyawa antibakteri merupakan senyawa nonpolar. Pada pengujian laboratorium menunjukkan kedua isolat teridentifikasi sebagai Streptococcus pyogenes.

Dari penelitian ini dapat disimpulkan fraksi etil asetat tinta cumi-cumi (Loligo sp.) memiliki efek antibakteri terhadap bakteri saluran akar gigi.
\end{abstract}

Kata kunci : bakteri saluran akar gigi, Streptococcus sp., tinta cumi-cumi, Loligo sp., efek antibakteri

\section{ABSTRACT}

Pulp necrosis is the death of the dental pulp, partially or completely, which is caused by the continued process of pulp inflammation or trauma. The treatment of pulp necrosis is endodontic therapy. Microorganisms that is remaining after preparation and after root canal filling is a major cause of endodontic treatment failure. Squid ink (Loligo sp.) has efficacy as an antibacterial. The purpose of this study was to determine the antibacterial effect of squid ink against the bacteria in dental root canal.

This study was an experimental laboratory research using Kirby-Bauer agar well diffusion method with modification. The squid ink was separated using solvent into ethyl acetate phase and aqueous phase by separatory funnel. Bacterias were isolated from pulp necrosis specimens, planted in BHA medium to obtained the bacteria colonies. Three isolates that were found, was tested with squid ink from ethyl acetate phase and water dissolved squid ink.

The result of this study showed the inhibition zone exist in squid ink from ethyl acetate phase against the three isolates. On the other hand, the absence of inhibition zone in water 
dissolved squid ink was informed that the antibacterial compound are non-polar compound. Laboratory test showed the two isolates were identified as Streptococcus pyogenes.

This study concluded that the ethyl acetate phase of squid ink (Loligo sp.) has an antibacterial effect against dental root canal bacteria.

Keywords : dental root canal bacteria, Streptococcus sp., squid ink, Loligo sp., antibacterial effect

\section{PENDAHULUAN}

Nekrosis pulpa adalah kematian pulpa, dapat sebagian atau seluruhnya, yang merupakan proses lanjutan dari radang pulpa akut maupun kronis atau terhentinya sirkulasi darah secara tibatiba akibat trauma. ${ }^{1,2}$ Nekrosis pulpa yang ditangani dengan ekstraksi merupakan salah satu penyebab kehilangan gigi asli dalam rongga mulut.

3 Berdasarkan hasil Riset Kesehatan Dasar (RISKESDAS) tahun 2007, prevalensi penduduk yang mempunyai masalah kesehatan gigi dan mulut sebesar $23,5 \%$, dan $17,6 \%$ penduduk telah kehilangan seluruh gigi aslinya. ${ }^{4}$ Kehilangan gigi ini dapat dicegah dengan mempertahankan gigi selama mungkin dalam rongga mulut melalui perawatan saluran akar gigi (endodontik). ${ }^{3}$

Keberhasilan perawatan saluran akar gigi bergantung dari berbagai faktor, namun salah satu penyebab utama kegagalan perawatan endodontik yakni mikroorganisme yang tersisa setelah preparasi ataupun setelah pengisian saluran akar gigi. 5 Sebesar 90\% mikroorganisme yang terdapat dalam saluran akar gigi yaitu bakteri anaerob yang didominasi oleh bakteri anaerob obligat, dan sebagian besar diantaranya merupakan organisme Gram positif. ${ }^{2,3}$ Oleh sebab itu, salah satu kunci keberhasilan perawatan endodontik ditentukan oleh pemilihan bahan antimikroba yang tepat.

Penggunaan antimikroba yang terlalu sering dalam jangka waktu lama serta penggunaan yang irasional dan berlebihan memudahkan perkembangan resistensi pada mikroba. Adanya efek samping terhadap tubuh penjamu pada penggunaan antimikroba pun menurunkan kualitas efektivitas obat dalam mengatasi mikroba penyebab infeksi. 6 Penggunaan antimikroba berspektrum luas dapat menyebabkan infeksi baru dari mikroba patogen oportunis, yang disebut dengan superinfeksi. Salah satu tindakan yang diambil untuk mengatasi superinfeksi dan resistensi mikroba yakni dengan melakukan biakan mikroba penyebab superinfeksi, tetapi bakteri anaerob obligat sebagai bakteri dominan penghuni saluran akar gigi yang sukar dibiakkan menjadi suatu kendala untuk memberikan antimikroba yang efektif terhadap bakteri tersebut. ${ }^{3,6}$

Kebutuhan terhadap obat-obatan alternatif dari alam yang efektif mengatasi infeksi polimikroba semakin mendesak untuk meningkatkan kualitas hidup manusia. Substansi bioaktif alami memiliki efek samping lebih minimal dibanding substansi sintetis sehingga lebih aman bagi tubuh hospes. ${ }^{7}$ Laut menyediakan produk-produk yang sangat berguna bagi masa depan pengobatan. Salah satu hasil laut yang memiliki khasiat farmasitika yaitu cumicumi, terutama tinta yang dihasilkannya.

Tinta cumi-cumi terbukti banyak berperan dalam dunia pengobatan alternatif serta memiliki jangkauan yang luas pada aplikasi terapeutik. ${ }^{7}$ Khasiat tinta cumi-cumi sebagai antiretroviral, antitumor, antioksidan, serta kemampuan melindungi sel dari kerusakan karena 
kemoterapi telah dilaporkan. $8, \quad 9, \quad 10$ Potensi antibakteri tinta cumi-cumi terhadap bakteri patogen pun telah banyak dipublikasikan. 7, 9, 11 Penelitian terakhir menunjukkan ekstrak tinta cumi-cumi memiliki efek antibakteri terhadap bakteri resisten betalaktam $E$. coli dan $K$. pneumoniae. ${ }^{7}$ Oleh karena itu, penelitian ini dilakukan untuk mengetahui efek antibakteri tinta cumicumi terhadap bakteri yang ada dalam saluran akar gigi.

\section{BAHAN DAN METODE}

Penelitian ini merupakan penelitian eksperimental laboratoris dengan rancangan post-test only disertai kelompok kontrol (post-test only group design) dengan 3 kali ulangan dan dilaksanakan di Balai Pengobatan Rumah Sakit Gigi dan Mulut Pendidikan Program Studi Kedokteran Gigi, serta di Laboratorium Riset Biomedik Fakultas Kedokteran Universitas Sam Ratulangi Manado.

\section{Fraksinasi tinta cumi-cumi}

Tinta cumi-cumi didapatkan dari cumi-cumi segar (Loligo sp.) yang ditangkap oleh nelayan lalu dicuci dengan air bersih yang mengalir dan kemudian dilakukan pembedahan untuk mengeluarkan kantung tintanya. Cumicumi diletakkan secara postero-ventral dan dibelah menggunakan gunting steril. Saluran tinta dipisahkan dengan saluran pencernaan dan organ lain menggunakan pinset steril. Saluran tinta dijepit menggunakan pinset steril dan kantung tinta dikeluarkan dari tubuh cumi-cumi, kemudian saluran tinta dipotong menggunakan gunting steril. Kantung tinta dikumpulkan dan ditampung dalam botol steril berwarna cokelat, lalu disimpan pada lemari pendingin dengan suhu $-20^{\circ} \mathrm{C}$ sebelum digunakan.

Fraksinasi tinta cumi-cumi dilakukan melalui pemisahan fasa larutan pada corong pisah. Kantung tinta diremas secara perlahan untuk mengeluarkan tintanya. Tinta cumi-cumi sebanyak $\pm 40 \mathrm{ml}$ beserta larutan etil asetat dan aquades sebagai pelarut masing-masing sebanyak $250 \mathrm{ml}$ dimasukkan ke dalam corong pisah, lalu dikocok dengan kuat. Setelah itu corong didiamkan agar pemisahan dua fasa larutan berlangsung, yakni fasa larut etil asetat dan fasa larut air. Tinta cumi-cumi pada fasa larut etil asetat dan fasa larut air dipisahkan dan dievaporasi menggunakan rotary vacuum evaporator, yang selanjutnya digunakan dalam pengujian antibakteri.

\section{Pengambilan sampel bakteri saluran akar gigi}

Penelitian ini menggunakan bakteri saluran akar anaerob fakultatif yang diambil dari gigi nekrosis pulpa secara total. Bakteri diambil dengan memasukkan poin absorben steril ke dalam saluran akar gigi selama 1 menit. Setelah itu poin absorben tersebut dikeluarkan dan dimasukkan ke dalam tabung reaksi yang mengandung media Brain Heart Infusion (BHI), lalu dimasukkan ke dalam desikator yang selanjutnya divakum untuk mengeluarkan udara di dalamnya. Sampel bakteri tersebut kemudian diisolasi untuk memisahkan tiap koloni yang ada, dengan cara menggoreskan kawat ose steril yang telah dimasukkan dalam tabung reaksi pada permukaan media Brain Heart Agar (BHA). Setelah itu dimasukkan ke dalam desikator lalu diinkubasi selama 24 jam dengan suhu $37^{\circ} \mathrm{C}$. Setelah 24 jam akan terbentuk berbagai koloni pada permukaan media agar. Tiap koloni yang seragam diambil salah satu koloninya menggunakan kawat ose steril kemudian digoreskan kembali pada permukaan media BHA berikutnya, selanjutnya dimasukkan dalam desikator dan diinkubasi selama 
24 jam dengan suhu $37^{\circ} \mathrm{C}$ kemudian diamati terbentuknya koloni tunggal yang bertumbuh pada media BHA. Koloni isolat yang terbentuk pada cawan petri diambil menggunakan kawat ose steril lalu digoreskan pada media nutrien agar miring. Isolat yang telah ditanam pada media tersebut lalu diinkubasi dalam inkubator selama 24 jam pada suhu $37^{\circ} \mathrm{C}$. Isolat diambil dari media Pengujian menggunakan metode difusi agar Kirby-Bauer yang dimodifikasi dengan cara sumuran, disertai kelompok kontrol berupa larutan amoksisilin sebagai kontrol positif dan pelarut etil asetat sebagai kontrol negatif. Inokulum disiapkan dengan menggunakan kapas lidi steril. Kapas lidi steril dimasukkan ke dalam suspensi isolat pada media BHI lalu dioleskan pada permukaan media agar Mueller Hinton secara merata. Setiap sumuran diisi dengan tinta cumi-cumi fraksi larut etil asetat, tinta cumi-cumi larut air, bubuk amoksisilin yang dilarutkan dengan akuades sebagai kontrol positif, dan pelarut etil asetat sebagai kontrol negatif, masing-masing sebanyak $100 \mu \mathrm{l}$ kemudian dimasukkan ke dalam desikator dan divakum lalu diinkubasi selama 24 jam pada suhu $37^{\circ} \mathrm{C}$. Konsentrasi tinta cumi-cumi pada kedua fraksi yang dihasilkan yakni 6,25 v/v, sedangkan konsentrasi amoksisilin agar miring dengan menggunakan kawat ose steril, kemudian dimasukkan ke dalam tabung reaksi berisi media BHI. Kekeruhan tabung reaksi disesuaikan dengan standar larutan baku McFarland sehingga kepadatan isolat sama dengan $1,5 \times 10^{8} \mathrm{CFU} / \mathrm{ml}$.

\section{Uji sensitivitas antibakteri invitro}

ditentukan berdasarkan konsentrasi penghambat minimal yaitu $2 \mathrm{mg} / \mathrm{ml}$.

Efek antibakteri diketahui dengan melihat terbentuknya daerah jernih (clear zone) di sekeliling sumuran sebagai daerah hambatan pertumbuhan bakteri. Pengukuran zona hambat dilakukan menggunakan kaliper dengan cara mengukur diameter terpanjang pada daerah jernih sebanyak dua kali pada posisi yang berbeda dan dirata-ratakan. Hasil pengukuran tersebut dihitung luasnya dan dikurangi luas sumuran yang mengacu pada luas lingkaran.

\section{HASIL}

Luas zona hambat yang terbentuk dihitung nilai rata-rata dan simpang bakunya. Gambaran nilai rerata beserta simpangan baku ini disajikan dalam diagram berikut untuk melihat perbandingan luas zona hambat antara kelompok perlakuan dan kelompok kontrol pada $S$. pyogenes dan isolat C.

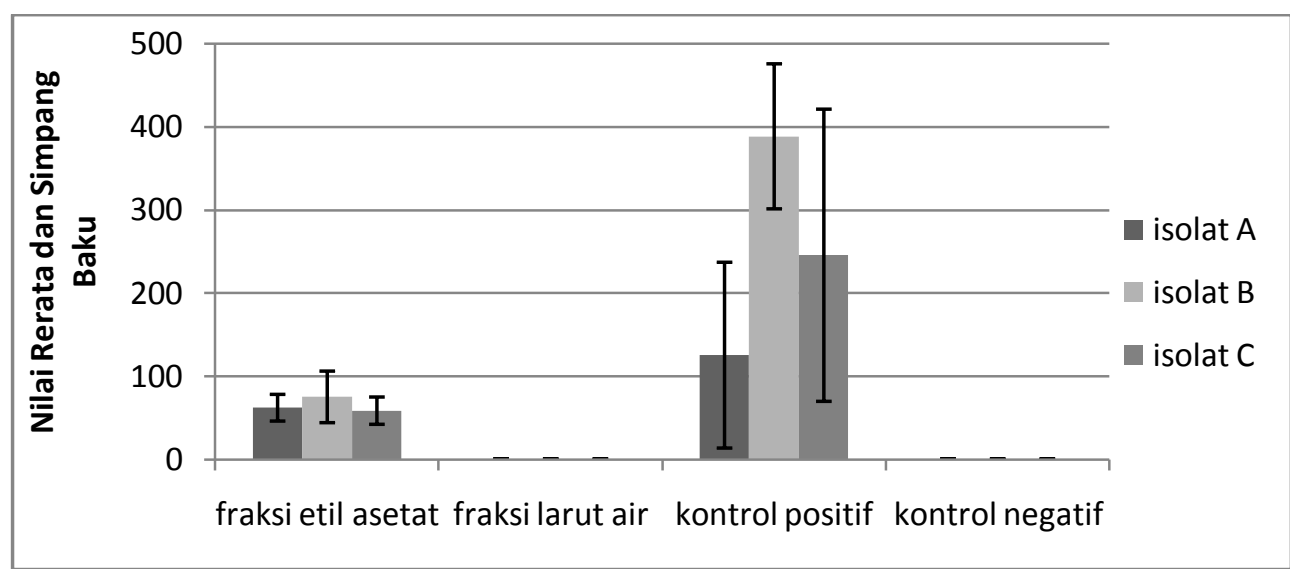

Gambar 7. Diagram rerata luas zona hambat terhadap Streptococcus pyogenes (isolat A dan B) serta isolat $\mathrm{C}$ 


\section{PEMBAHASAN}

Hasil pengujian antibakteri memperlihatkan tinta cumi-cumi Loligo sp. fraksi larut etil asetat memiliki efek antibakteri, sebaliknya tinta cumi-cumi Loligo sp. fraksi larut air tidak memiliki efek antibakteri. Hal ini membuktikan bahwa senyawa aktif antibakteri tinta cumi-cumi tersebut termasuk senyawa non-polar, walaupun tinta cumi-cumi itu sendiri terlarut dalam pelarut polar seperti akuades.

Hasil penelitian menunjukkan ratarata luas zona hambat etil asetat tinta Loligo sp. terhadap S. pyogenes isolat A dan $B$ hampir seragam, namun rata-rata luas zona hambat pada kontrol positif berupa amoksisilin berbeda. Nilai rerata luas zona hambat pada kontrol positif terhadap $S$. pyogenes isolat A lebih rendah dibandingkan terhadap $S$. pyogenes isolat $\mathrm{B}$. Hal ini menunjukkan bahwa $S$. pyogenes isolat B lebih sensitif terhadap amoksisilin dibandingkan S. pyogenes isolat A pada konsentrasi yang sama. Perbedaan kepekaan ini kemungkinan disebabkan oleh perbedaan varian $S$. pyogenes antara isolat A dan B dan suatu mekanisme resistensi oleh $S$. pyogenes isolat A terhadap larutan amoksisilin. Mekanisme resistensi $S$. pyogenes isolat A disebabkan oleh terjadinya mutasi gen yang menghasilkan enzim betalaktamase sehingga memecah cincin betalaktam pada amoksisilin. ${ }^{6}$

Hasil yang berbeda diperlihatkan pada kelompok perlakuan tinta cumicumi fraksi larut etil asetat. Tinta cumicumi fraksi larut etil asetat memiliki kepekaan yang hampir sebanding pada semua isolat uji, namun berbeda kepekaan terhadap larutan antibiotik amoksisilin. Hal ini menunjukkan bahwa mekanisme aksi antibakteri yang terkandung dalam tinta cumi-cumi kemungkinan besar berbeda dengan mekanisme aksi amoksisilin. Senyawa antibakteri yang terkandung dalam tinta cumi-cumi diduga tidak berperan dalam menghambat sintesis dinding sel seperti mekanisme aksi amoksisilin. Beberapa mekanisme yang dapat menjadi probabilitas efek antibakteri yang terdapat pada tinta cumi-cumi yaitu penghambatan metabolisme sel, sintesis protein sel, sintesis asam nukleat sel, serta mengganggu permeabilitas membran sel mikroba.

Hasil penelitian juga menunjukkan zona hambat amoksisilin lebih luas dibandingkan dengan zona hambat tinta cumi-cumi fraksi larut etil asetat. Hal ini menunjukkan efek antibakteri terhadap bakteri $S$. pyogenes dan isolat $\mathrm{C}$ yang dimiliki oleh amoksisilin lebih baik dibandingkan tinta cumi-cumi fraksi etil asetat. Efek antibakteri amoksisilin yang lebih efektif dari tinta cumi-cumi fraksi etil asetat disebabkan oleh kemampuannya dalam menghambat pembentukan mukopeptida yang diperlukan untuk sintesis dinding sel bakteri. ${ }^{6}$ Sintesis dinding sel yang tidak sempurna menyebabkan sel-sel bakteri menyerap air melalui osmosis sehingga tekanan osmotik intraseluler pada bakteri Gram positif dan negatif mencapai 3-5 kali lebih tinggi dibandingkan tekanan eksternal sel. ${ }^{12}$

Kemampuan suatu zat antimikroba dalam menghambat maupun membunuh mikroba ditentukan oleh kepekaan ataupun kekebalan bakteri terhadap zat tersebut dalam jumlah yang kecil. ${ }^{6,13}$ Zona hambat yang terbentuk pada tinta cumi-cumi fraksi larut etil asetat sangat kecil. Pembentukan zona hambat yang terlalu kecil kemungkinan disebabkan oleh pengenceran pada tinta cumi-cumi Loligo sp. yang didapat sehingga penggunaan konsentrasi tinta cumicumi tidak terlalu pekat. Hal ini mengakibatkan tinta tersebut terdilusi 
pada media MHA, sehingga zona hambat yang terbentuk diduga tidak optimal. Konsentrasi tinta cumi-cumi yang tepat dapat memberikan efek antibakteri secara optimal.

\section{KESIMPULAN}

Berdasarkan hasil penelitian yang telah diuraikan di atas, tinta cumi-cumi Loligo sp. fraksi larut etil asetat memiliki efek antibakteri terhadap $S$. pyogenes dan salah satu isolat yang diisolasi dari saluran akar gigi nekrosis. Bila kemampuan antibakteri dari tinta cumi-cumi ini dibandingkan dengan larutan amoksisilin, tinta tersebut masih kurang efektif dalam menghambat bakteri-bakteri dalam saluran akar gigi nekrosis.

\section{Daftar Pustaka}

1. Tarigan R. Perawatan pulpa gigi (endodonti). ed. 2. In: Juwono L, editor. Jakarta: EGC; 2006. h. 35-7

2. Grossman L, Oliet S, Del Rio C. Ilmu endodontik dalam praktek. ed. 11. Terjemahan oleh Abyono R. In: Suryo S, editor. Jakarta: EGC; 2012. h. 82-4, 255-7

3. Walton R, Torabinejad M. Prinsip dan praktik ilmu endodonsi. $3^{\text {rd }} \mathrm{ed}$. Terjemahan oleh Sumawinata N. In: Juwono L, editor. Jakarta: EGC; 2008. h.45, 77, 205-93

4. Kementrian Kesehatan. Laporan hasil riset kesehatan dasar, RISKESDAS Indonesia tahun 2007. Jakarta: Depkes; 2008. h. 130-47

5. Mulyawati E. Peran bahan disinfeksi pada perawatan saluran akar. Maj Ked Gi. Vol 18(2) Desember 2011 h. 205-9

6. Departemen Farmakologi dan Terapeutik Fakultas Kedokteran
Universitas Indonesia. Farmakologi dan terapi. Ed. 5. Jakarta: Badan Penerbit FKUI; 2007. h. 585-9, 664-8

7. Smiline GA.S, Vijayshree PJ, Pandi SK, Hariprasad P, Raghuraman R. Antibacterial effect of squid ink on ESBL producing strains of Escherichia coli and Klebsiella pneumoniae. Indian J. Mar. Sci. Vol 41(4) Agustus 2012 p. 338-43.

8. Jie-Ping Z, Guang W, Jiang-Hua S, Jiang-Qiu P, Kun L, Huang Y, et al. Protective effects of squid ink extract towards hemopoietic injuries induced by cyclophosphamine. Mar Drugs. 2009, 7, p. 9-18.

9. Nair JR, Pillai D, Joseph SM, Gomathi P. Senan PV, Sherief PM. Cephalopod research and bioactive substances. Indian J. Mar. Sci. Vol 40(1) Februari 2011 p. 13-27

10. Nazeer RA, Naqash SY. In vitro antioxidant activity of two moluscs, Loligo duvauceli Orbigny and Donax cuneatus Linnaeus, by solvent extraction methods. Med J Nutrition Metab. 2013. Vol. 6(1). p. 17-21.

11. Smiline GA.S, Vijayshree PJ, Pandi SK, Hariprasad P, Raghuraman R. Isolation and characterization of Lolduvin-S: A novel antimicrobial protein from the ink of indian squid Loligo duvauceli. IJCRR. 2011. Vol 3(7). p. 4-14

12. Rao R, Kaur SP, Nanda S. Amoxicillin: a broad spectrum antibiotic. Int J Pharm Sci. 2011. Vol 3(3). p. 30-7

13. Harmita, Radji M. Buku ajar analisis hayati. Ed. 3. Jakarta: EGC; 2008. h. 1-2 